\title{
Genetic variation of silver fir progeny from Tisovik Reserve population determined via microsatellite and isozyme markers
}

\author{
Ewa Maria Pawlaczyk $\bowtie$, Alina Baczkiewicz, Katarzyna Buczkowska, Maria Anna Bobowicz \\ Adam Mickiewicz University in Poznań, Faculty of Biology, Department of Genetics, Umultowska 89, 61-614 Poznań, \\ Poland, e-mail: ewapaw@amu.edu.pl
}

\section{Abstract}

Progeny from 19 family lines of silver fir (Abies alba Mill.) from a small, native and isolated population from the Tisovik Reserve (Belarusian part of Białowieża Primeval Forest) growing in an experimental plot near Hajnówka (Polish part of Białowieża Primeval Forest) were analysed in terms of 4 nuclear microsatellite DNA loci and 9 isozyme systems with 14 loci. The aim of this study was to determine the genetic variation within and between progeny lines. Analysis of isozyme loci showed that all progeny lines, except the progeny lines T6 and T16, were characterised by an excess of heterozygotes and $20 \%$ of the detected variation occurred between progeny. Progeny formed two groups. Microsatellite loci showed that 6 progeny lines demonstrated an excess of heterozygotes and 12 an excess of homozygotes. On an average, the population was in the Hardy-Weinberg equilibrium. Analysis of molecular variance (AMOVA) showed that $14 \%$ of the detected variation occurred between offspring and the remaining $86 \%$ within progeny lines. The most distinct progeny line was $\mathrm{T} 1$, where the highest number of alleles per locus was detected. Generally, progeny of Tisovik is characterised by high level of differentiation as the offspring of isolated population that have limited number of individuals to crossing (only 20). In some progeny line, the private alleles that are detected may be the result of pollination from Polish part of Białowieża Forest where in 1920s and 1930s of XX century had planted the seedling of silver fir of unknown origin. The substructuring of population is observed, and the detected deficiency of heterozygotes may be ostensible as a result of the Wahlund effect. Such pattern of genetic structure could also be an effect of harsh environmental conditions exerting selection pressure and modifying the genetic composition of this population.

\section{KEY WORDS}

european silver fir, genetic diversity, isolated population, isozyme analysis, nuclear microsatellite DNA, progeny

\section{INTRODUCTION}

In terms of its economic and ecological value, silver fir (Abies alba Mill.) is one of the most important forest trees growing in the mountains of Central Europe. In the northern part of it species distribution, this tree occurs on lowlands. In these regions, fir is characterised by relatively small variation and lower adaptability to stress in comparison to other Pinaceae species, especially Scots pine and Norway spruce. The reason for 
this seems to be the history of fir (the small number of glacial refugia) and populational genetic processes such as mutation, drift and selection during and after postglacial migration to the northern part of its natural distribution (Larsen 1986; Konnert and Bergman 1995; Breitenbach-Dorfer et al. 1997; Vendramin et al. 1999; Longauer et al. 2003; Liepelt et al. 2009). These populational processes were induced inter alia by climatic fluctuations. The reduced adaptability because of insufficient genetic variation is assumed and is, thus, the main predisposing factor exerting a permanent stress on silver fir and thereby making it sensitive to other factors such as frost, drought, acidification and biotic pests (Longauer et al. 2003). Another reason for reduced variation is the dieback of fir caused by anthropogenic factors such as inappropriate management systems (mainly cultivating fast-growing needle trees such as Scots pine and Norway spruce), air pollution, insect pests and others. Dieback of this species is especially evident in the northern part of fir distribution (Longauer 1994).

The Białowieża Primeval Forest is the only remaining natural lowland forest in Europe, where a small, natural and isolated population of fir can be found in the Tisovik Reserve. This population is located in Belarus $-120 \mathrm{~km}$ north of the natural range limit of this species and is a remnant of the post-glacial migration and contraction of the silver fir distribution. The Tisovik Reserve is the last site in the Białowieża Forest where fir occurs naturally and should be recognised as the fir locus classicus (Korczyk et al. 1997). A detailed description of the Tisovik Reserve is given in papers by Mejnartowicz (1996a, 1996b), Korczyk et al. (1997), Korczyk (1999, 2015a, 2015b), Goncharenko and Savitsky (2000), and Pawlaczyk et al. (2005). The number of firs in Tisovik has never been abundant. According to the above authors, the number of fir trees ranged from 300 to 100 (between 1829, when this site was discovered by Górski (1829), and 1939, the beginning World War II). Currently, there are only 20 mature fir trees. This site is limited not only by the very small area where fir is growing (a mineral forest islet that is surrounded by the vast 'Dziki Nikor' peat-land) but also by animals that browse and graze the trees and seedlings and by local people who cut out trees. Decisive in the survival of this fir population, despite these many unfavourable factors, has been its capacity for intensive seeding and natural recovery. However, research conducted in 1995 showed that seeds germinated less and $60 \%$ was parasitized by monofagous entomofauna (mainly Megastigmus suspectus Borr. from Hymenoptera and Resseliella piceae Seitn. from Diptera) (Korczyk et al. 1997). These two species occur in Poland and Belarus only on European silver fir and came to Białowieża Forest together with fir in the Holocene climate optimum period and stayed with fir as a relict (Korczyk et al. 1997). Such a high level of seed parasitisation is the result of the very small number of fir trees. These facts suggest that Tisovik is probably a declining population, which could go through a 'bottle neck' and may completely disappear (Mejnartowicz 1996a, 1996b). In response to this threat, the preservation of its gene resource and the description of its diversity are an urgent priority. Therefore, in 1995, a plantation with Tisovik fir offspring was established in Hajnówka Forest District (Polish part of Białowieża Primeval Forest).

Earlier studies carried out on isozyme markers showed that Tisovik population were characterised by an excess of heterozygosity (Mejnarowicz 1996a, 1996b; Goncharenko and Savitski 2000), which may be the result of a long selection for adaptability to the rapidly changing environmental factors in the Białowieża Primeval Forest after the last glacial period. Heterozygous trees are expected to be more adaptable because natural selection reduces the frequencies of homozygotes in natural forest populations (Stern and Roche 1974).

The genetic analysis may provide essential information that is important to understand the mechanisms that allow a population to exist beyond the species natural distribution in a small and isolated site, where there are often extreme conditions (in the case of fir, e.g. low soil humidity, lower than $4^{\circ} \mathrm{C}$ of average temperature in February and destructive human activities over many years). The genetic variability may be a source of information for institutions dealing with conservation and provide information about the source of genetic variation and plasticity of silver fir in protected areas such as nature reserves, which bring together some of the most valuable and unique populations. Understanding the variability of the offspring will help trace trends and microevolutionary processes that are occurring in small and isolated populations. 
The aim of the investigations was to characterise the genetic variation within and between the progeny of the Tisovik population on the basis of isozyme and nuclear microsatellite DNA loci and to compare the results obtained from these two markers. The general purpose will be to check whether a high level of heterozygosity discovered by Mejnartowicz (1996a, 1996b) and Goncharenko and Savitsky (2000) will be maintained in progeny.

\section{Material AND MEthods}

\section{Material}

In order to protect the gene pool and detect genetic variation in silver fir from the Tisovik Reserve, the provenance-progeny experiment plot was established by Prof Adolf F. Korczyk from the Forest Research Institute in Białowieża and the Białystok University of Technology. In 1995, seeds from 20 silver fir trees were collected and sowed in a forest nursery in Nawojowa (Beskid Sądecki). Next, in 1998, three-year-old seedlings were moved to an experimental plot in Hajnówka Forest District in Poland (Leśna, Wilczy Jar, section 416Ag/416Cf). The area of silviculture is about 0.225 ha. Detailed description of seed collection and seedlings cultivation is given in Korczyk papers (1999, 2015b).

Plant material was collected from the progeny of 19 maternal trees from Tisovik Reserve. Each progeny line was represented by $8-15$ trees. In sum, 274 progeny trees were studied. For analysis, 1-year-old needles and vegetative buds were collected from 15-year-old progeny in 2010. The plant material was stored in a freezer at a temperature of $-20^{\circ} \mathrm{C}$ until the beginning of analysis.

\section{Methods}

\section{Isozyme separation}

Isozyme separation was conducted according to the procedure described by Cheliak and Pitel (1984) and Hussendörfer et al. (1995). Crude cell extract was prepared by homogenisation of dormant buds in $80 \mathrm{ml}$ of $0.2 \mathrm{M}$ Tris- $\mathrm{HCl}$ extraction buffer ( $1 \%$ ethylenediaminetetraacetic acid (EDTA) II, polyvidone (PVP) 40, PVP 80, TWEEN, polyethylene glycol, sodium ascorbate, 2-mercaptoethanol and $0.01 \%$ dithiothreitol, $\mathrm{pH} 7.2$ ) and then paper wicks (Watmann 3MM) were soaked. Isozymes were separated in $10 \%$ starch gel in two buffer systems: (a) Tris-citrate ( $\mathrm{pH} 8.2$ ), lithium-borate
( $\mathrm{pH}$ 8.3) and (b) Tris-citrate $(\mathrm{pH} 8.0)$ in a dilution of electrode buffer 1:15. The enzymes stained and buffer systems used for their resolution are listed in Table 1. Lithium-borate gels were separated at a constant voltage ( $240 \mathrm{~V}$ by $5 \mathrm{~h}$ ), and Tris-citrate gels were separated at a constant current ( $75 \mathrm{~mA}$ by $4 \mathrm{~h}$ ). After separation, the isozymes were detected on the gel slabs by using the staining methods of Cheliak and Pitel (1984) and Hussendörfer et al. (1995).

Table 1. List of studied enzymes and their abbreviations (Abbr.), enzyme commission number (E.C.) and buffer systems: A - Tris-citrate ( $\mathrm{pH} 8.2$ ), lithium-borate ( $\mathrm{pH} 8.3$ ); $\mathrm{B}$ - Tris-citrate ( $\mathrm{pH} 8.0$ ) in a dilution of electrode buffer 1:15

\begin{tabular}{|l|c|c|c|}
\hline \multicolumn{1}{|c|}{ Enzyme } & Abbr. & E.C. & $\begin{array}{c}\text { Buffer } \\
\text { system }\end{array}$ \\
\hline Glutamate dehydrogenase & GDH & 1.4 .1 .2 & A \\
\hline $\begin{array}{l}\text { Glutamate oxaloacetate } \\
\text { transaminase }\end{array}$ & GOT & 2.6 .1 .1 & A \\
\hline Leucine aminopeptidase & LAP & 3.4 .11 .1 & A \\
\hline Glucose phosphate isomerase & PGI & 5.3 .1 .9$. & A \\
\hline Isocitrate dehydrogenase & IDH & 1.1 .1 .41 & B \\
\hline Shikimate dehydrogenase & SDH & 1.1 .1 .25 & B \\
\hline Phosphoglucomutase & PGM & 5.4 .2 .2 & B \\
\hline Phosphogluconate dehydrogenase & PGD & 1.1 .1 .44 & B \\
\hline Malate dehydrogenase & MDH & 1.1 .1 .37 & B \\
\hline
\end{tabular}

\section{DNA extraction}

Genomic DNA from fir needles and buds tissue was extracted. Frozen needles and buds (100 mg of tissue) were powdered in liquid nitrogen, and the total genomic DNA was extracted using a modified ATMAB method (Doyle and Doyle, 1990) and then dissolved in $0.1 \times \mathrm{TE}$ buffer (10 mM Tris-HCl, pH 8.0; 1 mM EDTA, pH 8.0) for subsequent use. The quality and quantity of extracted DNA were measured on a Nanodrop ${ }^{\text {TM }}$ ND-1000 (ThermoScientific) spectrophotometer and diluted to a final concentration of $20 \mathrm{ng} / \mu \mathrm{l}$.

\section{SSR amplification}

Four nrSSR markers that gave satisfactory amplification products in the analysed fir species were selected from the published literature (Cremer et al. 2006). However, the amplification and polymorphism potential for eight primer pairs of nuclear microsatellite loci were checked: SF 1, SF 2, SF 8, SF 83, SF 324, SF 333, SF b5 
and SF g36. Some of these markers were monomorphic or did not give an amplification of products or showed unstable amplification. Four markers - SF 333, SF 1, SF 324 and SF b5 - were classified as variable and stably amplified and were then used in this study (Tab. 2).

Table 2. Characteristics of the used primers

\begin{tabular}{|c|c|c|c|}
\hline Primer & Motive & $\begin{array}{c}\text { Allele } \\
\text { size (bp) }\end{array}$ & Primer sequence \\
\hline $\begin{array}{l}\text { SF } 333 \\
\text { (DQ218463) }\end{array}$ & $\begin{array}{l}(\mathrm{CA})_{12} \\
(\mathrm{TA})_{4}\end{array}$ & $166-178$ & $\begin{array}{l}\text { 5'-ATTTGTTCATTTT } \\
\text { GGTCCTG-3' } \\
\text { 5'-ACACAGGAAAAA } \\
\text { GTCGGTAA-3' }\end{array}$ \\
\hline $\begin{array}{l}\text { SF 1 } \\
\text { (DQ218453) }\end{array}$ & $(\mathrm{CCG})_{9}$ & $209-221$ & $\begin{array}{l}\text { 5'-TTGACGTGATTAA } \\
\text { CAATCCA -3' } \\
\text { 5'-AAGAACGACACC } \\
\text { ATTCTCAC-3' }\end{array}$ \\
\hline $\begin{array}{l}\text { SF } 324 \\
\text { (DQ218461) }\end{array}$ & $(\mathrm{CCG})_{8}$ & $106-112$ & $\begin{array}{l}\text { 5'-TTTGAACGGAAAT } \\
\text { CAAATTCC-3' } \\
\text { 5'-AAGAACGACACC } \\
\text { ATTCTCAC-3' }\end{array}$ \\
\hline $\begin{array}{l}\text { SF b5 } \\
\text { (DQ218455) }\end{array}$ & $(\mathrm{CT})_{15}$ & $130-148$ & $\begin{array}{l}\text { 5'-AAAAAGCATCAC } \\
\text { TTTTCTCG-3' } \\
\text { 5'-AAGAGGAGGGGA } \\
\text { GTTACAAG-3' }\end{array}$ \\
\hline
\end{tabular}

Primers are from Cremer et al. (2006).

Polymerase chain reaction (PCR) was performed in a 2720 Thermal Cycler (Applied Biosystems ${ }^{\odot}$ Waltham, Massachusetts, USA). Each amplification reaction contained $1 \times$ reaction buffer (Novazym), $0.2 \mathrm{mM}$ of each deoxynucleotide, $0.25 \mu \mathrm{M}$ of forward and reverse primer and $0.5 \mathrm{U}$ of HiFiTaq DNA polymerase (Novazym), approximately $50 \mathrm{ng}$ of genomic DNA and de-ionised water to a total volume of $10 \mu$. The forward primer of each primer pair was fluorescent labelled with 6FAM (SF 1), VIC (SF 324), NED (SF b5) and PET (SF 333) dye (Applied Biosystems ${ }^{\odot}$ Waltham, Massachusetts, USA) at its $5^{\prime}$ end to avoid the mistakes when reading the similar variants lengths of different amplificated loci.

The PCRs were completed using the following touchdown protocol: $5 \mathrm{~min}$ at $94^{\circ} \mathrm{C}$ followed by $10 \mathrm{cy}-$ cles of $30 \mathrm{~s}$ at $94^{\circ} \mathrm{C}, 30 \mathrm{~s}$ at $60^{\circ} \mathrm{C}$ and $30 \mathrm{~s}$ at $72^{\circ} \mathrm{C}$; followed by 25 cycles of $30 \mathrm{~s}$ at $94^{\circ} \mathrm{C}, 50 \mathrm{~s}$ at $50^{\circ} \mathrm{C}$ and 40 s at $72^{\circ} \mathrm{C}$; followed by a 7 min extension at $72^{\circ} \mathrm{C}$ and an indefinite hold at $4^{\circ} \mathrm{C}$.

PCR products were separated with a 3130xl Genetic Analyzer (Applied Biosystems ${ }^{\odot}$ ) capillary electrophoresis system with GeneScan ${ }^{\mathrm{TM}} 600 \mathrm{LIZ}^{\mathrm{TM}}$ as an internal size standard. Individuals were analysed and genotyped using GeneMapper version 3.7 software (Applied Biosystems $^{\odot}$ ).

\section{Data analysis and statistical methods}

For each isozyme (using PopGene32 by Yeh et al. (2000)) and microsatellite locus (using GenAlEx by Peakall and Smouse (2006)), the number of alleles (A), level of inbreeding amongst individuals within in each progeny $\left(\mathrm{F}_{\mathrm{IS}}\right)$, overall level of inbreeding in the studied population $\left(\mathrm{F}_{\mathrm{IT}}\right)$, measure of genetic differentiation amongst progeny lines $\left(\mathrm{F}_{\mathrm{ST}}\right)$, gene flow $(\mathrm{Nm})$, expected $\left(\mathrm{H}_{\mathrm{E}}\right)$ and observed heterozygosity $\left(\mathrm{H}_{\mathrm{O}}\right)$ were estimated. The Hardy-Weinberg exact test of heterozygote deficiency (HWE) was computed using Genepop (Raymond and Rousset 1995) program. Gene flow $\left(\mathrm{N}_{\mathrm{m}}\right)$ was estimated using Wright's (1978) formula: $\mathrm{N}_{\mathrm{m}}=0.25\left(1-\mathrm{F}_{\mathrm{ST}}\right) / \mathrm{F}_{\mathrm{ST}}$. For microsatellite loci, the number of null alleles was calculated using Micro-Checker 2.2.3 (van Oosterhout et al. 2004; 2006), and for isozyme markers, the Ewens-Watterson test for neutrality (Watterson 1977) was performed using PopGene32.

For both markers in each progeny line, the number of private alleles $\left(A_{P}\right)$ and the mean number of alleles per locus $\left(A_{L}\right)$ were computed using GenAlEx. In addition, the percentage of polymorphic loci ( $\mathrm{P} \%)$ for isozymes and allelic richness $\left(A_{R}\right)$ for microsatellite were calculated using PopGene32 and FSTAT v. 2.9.3.2, respectively (Goudet 1995; 2001).

The UPGMA (Unweighted Pair Group Method with Arithmetic Mean) dendrograms for both markers based on the Nei (Nei 1972) genetic distance were constructed using MEGA software (Tamura et al. 2013). To calculate the Nei genetic distance (Nei 1972) between each pair of progeny lines, the PopGene32 (Yeh et al. 2000) was used.

In addition, to estimate the genetic differentiation amongst progeny lines, hierarchical AMOVA was conducted using GenAIEx v.6.4 software (Peakall and Smouse 2006) for both markers. AMOVA was used to describe the percentage share of genetic diversity within and amongst progeny lines in terms of the total genetic diversity. The level of genetic differentiation between populations was estimated using the $\Phi$ statistic (an analogue to F). Statistical significance was determined by random permutation, with the number of permutations set to 999 . 


\section{Results}

Analysis of isozyme markers in the 9 enzyme systems, 14 isozyme loci (Gdh, Got-A, Got-B, Idh, Lap, Mdh-A, Mdh-B, Pgd-B, Pgi-A, Pgi-B, Pgm-A, Pgm-B, Sdh-A and $S d h-B)$ were detected. The parameters for isozyme loci were given in Table 3. Of the 14 loci examined, two loci ( $S d h-A$ and $P g m-A$ ) were monomorphic in all the studied progeny lines and displayed a homozygous pattern, so they were removed from further analyses. The re- maining loci were polymorphic, with two to four alleles (A). Most polymorphic loci have two or three alleles, with an average of 2.6; only in Pgi-B and Gdh, four alleles were found.

The mean value of the inbreeding coefficient $\left(\mathrm{F}_{\mathrm{IT}}\right)$ indicates an excess of heterozygotes. Six loci showed a deficit and six an excess of heterozygosity, in comparison with the expected levels. The genetic differentiation $\left(\mathrm{F}_{\mathrm{ST}}\right)$ calculated over polymorphic loci was at a mid level and the level of gene flow $(\mathrm{Nm})$ between the studied

Table 3a. Genetic parameters for polymorphic isozyme loci: A - number of alleles; $\mathrm{F}_{\mathrm{IS}}-$ level of inbreeding amongst individuals within each progeny; $\mathrm{F}_{\mathrm{IT}}$ - overall level of inbreeding in studied populations; $\mathrm{F}_{\mathrm{ST}}-$ measure of genetic differentiation amongst progeny lines; $\mathrm{Nm}$ - gene flow; Ho and $\mathrm{He}$ - observed and expected heterozygosity, respectively; HWE - the Hardy-Weinberg exact test of heterozygote deficiency, ${ }^{* * *}-\mathrm{p}<0.001,{ }^{* *}-\mathrm{p}<0.01, \mathrm{~ns}-\mathrm{p}>0.05$

\begin{tabular}{|c|c|c|c|c|c|c|c|c|}
\hline Locus & A & $\mathrm{F}_{\mathrm{IS}}$ & $\mathrm{F}_{\mathrm{IT}}$ & $\mathrm{F}_{\mathrm{ST}}$ & $\mathrm{Nm}$ & Ho & $\mathrm{He}$ & HWE \\
\hline$G d h$ & 4 & -0.053 & 0.169 & 0.211 & 0.936 & 0.168 & 0.203 & $* * *$ \\
\hline Got-A & 2 & -0.287 & -0.073 & 0.166 & 1.256 & 0.137 & 0.128 & ns \\
\hline Got-B & 2 & -0.163 & -0.027 & 0.117 & 1.891 & 0.053 & 0.051 & $\mathrm{~ns}$ \\
\hline$I d h$ & 3 & -0.045 & 0.104 & 0.143 & 1.499 & 0.242 & 0.270 & $* *$ \\
\hline Lap & 2 & -0.094 & 0.045 & 0.126 & 1.727 & 0.147 & 0.154 & ns \\
\hline$M d h-\mathrm{A}$ & 2 & -0.594 & -0.476 & 0.074 & 3.145 & 0.726 & 0.492 & $* * *$ \\
\hline$M d h-\mathrm{B}$ & 3 & -0.519 & -0.289 & 0.152 & 1.400 & 0.811 & 0.629 & $* *$ \\
\hline Pgi-A & 3 & 0.200 & 0.481 & 0.351 & 0.463 & 0.042 & 0.081 & $* * *$ \\
\hline Pgi-B & 4 & -0.349 & -0.159 & 0.140 & 1.531 & 0.737 & 0.636 & $\mathrm{~ns}$ \\
\hline Pgm-B & 2 & -0.026 & 0.156 & 0.177 & 1.165 & 0.084 & 0.099 & ns \\
\hline$P g d-\mathrm{B}$ & 2 & -0.601 & -0.485 & 0.072 & 3.199 & 0.726 & 0.489 & $* * *$ \\
\hline$S d h-\mathrm{B}$ & 2 & 0.004 & 0.272 & 0.269 & 0.679 & 0.263 & 0.362 & $* *$ \\
\hline Mean & 2.6 & -0.210 & -0.024 & 0.166 & 1.349 & 0.345 & 0.299 & \\
\hline SE & 0.229 & 0.069 & 0.078 & 0.021 & 0.259 & 0.089 & 0.062 & \\
\hline
\end{tabular}

Table 3b. Genetic parameters for microsatellite loci: A - number of alleles; $\mathrm{F}_{\text {IS }}$ - level of inbreeding amongst individuals within each progeny; $F_{\mathrm{IT}}$ - overall level of inbreeding in studied populations; $\mathrm{F}_{\mathrm{ST}}$ - measure of genetic differentiation amongst progeny lines; $\mathrm{Nm}$ - gene flow; Ho and $\mathrm{He}$ - observed and expected heterozygosity, respectively; HWE - the Hardy-Weinberg exact test of heterozygote deficiency, $* * *-p<0.001$, ns $-p>0.05$

\begin{tabular}{|l|c|c|c|c|c|c|c|c|c|}
\hline Locus & $\mathrm{A}$ & $\mathrm{F}_{\mathrm{IS}}$ & $\mathrm{F}_{\mathrm{IT}}$ & $\mathrm{F}_{\mathrm{ST}}$ & $\mathrm{Nm}$ & Ho & He & $\begin{array}{c}\text { HWE } \\
\text { Proportion of } \\
\text { null alleles }\end{array}$ \\
\hline SF 333 & 6 & 0.152 & 0.224 & 0.115 & 1.930 & 0.552 & 0.658 & $* * *$ & 0.105 \\
\hline SF 1 & 4 & -0.276 & -0.151 & 0.114 & 1.946 & 0.386 & 0.303 & $\mathrm{~ns}$ & -0.092 \\
\hline SF 324 & 4 & 0.150 & 0.193 & 0.085 & 2.708 & 0.137 & 0.161 & $\mathrm{~ns}$ & 0.067 \\
\hline SF b5 & 6 & 0.443 & 0.480 & 0.106 & 2.105 & 0.062 & 0.110 & $* * *$ & 0.132 \\
\hline Total & 20 & 0.073 & 0.149 & & & & & $\mathrm{~ns}$ & \\
\hline Mean & 5.0 & 0.1171 & 0.1865 & 0.105 & 2.172 & 0.2840 & 0.3080 & & 0.0530 \\
\hline SE & & 0.148 & 0.130 & 0.007 & 0.183 & 0.113 & 0.124 & & 0.050 \\
\hline
\end{tabular}


progeny lines was 1.349 migrants per generation. In loci $G d h, M d h-A, M d h-B$ and $P g d-B$, an exact test for the Hardy-Weinberg equilibrium indicated a significant excess of heterozygotes, but in the loci Pgi-A and $S d h-B$, this test showed a significant excess of homozygotes $\left(\mathrm{F}_{\mathrm{IS}}\right)$. Observed heterozygosity $\left(\mathrm{H}_{\mathrm{O}}\right)$ across the loci for all samples was higher than the mean expected heterozygosity $\left(\mathrm{H}_{\mathrm{E}}\right)$ under the Hardy-Weinberg expectations. The Ewens-Watterson test for neutrality for each locus showed that the allele frequencies at all loci were selectively neutral in the studied population.

In the whole population of Tisovik, 31 alleles were detected, 4 of them had a frequency of less than 0.05 and 1 was very rare $(<0.01)$. The parameters of genetic variation for each progeny line were given in Table 4 . Two private alleles $\left(\mathrm{A}_{\mathrm{P}}\right)$ were detected - in progeny line $\mathrm{T} 9$ (Pgi-A allele 1) and in T13 (Pgi-B allele 3). The percentage of polymorphic loci ( $\mathrm{P} \%$ ) within the studied progeny lines ranged from 42.86 (T1) to 71.43 (T13), with a mean of 53.76; however, within the whole population, this percentage was $85.71 \%$. The lowest value of mean number of alleles per locus $\left(\mathrm{A}_{\mathrm{L}}\right)$ was noted in progeny lines $\mathrm{T} 1$ and $\mathrm{T} 8$, and the highest in T29. The mean number of alleles per locus $\left(A_{L}\right)$ for the whole population was 2.36.

The highest values of the observed $\left(\mathrm{H}_{\mathrm{O}}\right)$ and the expected $\left(\mathrm{H}_{\mathrm{E}}\right)$ heterozygosity were in progeny line $\mathrm{T} 5$, and this was even higher than that in the population. Fixation indices $\mathrm{F}_{\mathrm{IS}}$ showed that all progeny lines except two (T6 and T16) exhibited an excess of heterozygotes.

Table 4. Parameters of genetic variation for each silver fir progeny line for isozyme and microsatellite loci: $\mathrm{N}$ - size of sample; $\mathrm{P} \%$ - percentage of polymorphic loci; $\mathrm{A}$ - number of alleles; $\mathrm{A}_{\mathrm{L}}$ - mean number of alleles per locus; $\mathrm{A}_{\mathrm{R}}-$ mean allelic richness; $\mathrm{A}_{\mathrm{P}}$ - private alleles; Ho and $\mathrm{He}$ - observed and expected heterozygosity, respectively; $\mathrm{F}_{\mathrm{IS}}$ - inbreeding coefficient

\begin{tabular}{|c|c|c|c|c|c|c|c|c|c|c|c|c|c|c|c|}
\hline \multirow{2}{*}{ 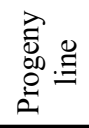 } & \multirow{2}{*}{$\mathrm{N}$} & \multicolumn{7}{|c|}{ Isozyme } & \multicolumn{7}{|c|}{ SSR } \\
\hline & & $\mathrm{P} \%$ & A & $\mathrm{A}_{\mathrm{L}}$ & $A_{P}$ & $\mathrm{H}_{\mathrm{O}}$ & $\mathrm{H}_{\mathrm{E}}$ & $\mathrm{F}_{\mathrm{IS}}$ & A & $\mathrm{A}_{\mathrm{L}}$ & $A_{R}$ & $A_{P}$ & Но & $\mathrm{He}$ & $\mathrm{F}_{\mathrm{IS}}$ \\
\hline $\mathrm{T} 1$ & 14 & 42.86 & 20 & 1.43 & 0 & 0.314 & 0.216 & -0.516 & 14 & 3.50 & 2.86 & 2 & 0.446 & 0.384 & -0.171 \\
\hline $\mathrm{T} 2$ & 15 & 50.00 & 23 & 1.64 & 0 & 0.286 & 0.235 & -0.312 & 9 & 2.25 & 2.11 & 0 & 0.117 & 0.247 & 0.536 \\
\hline T3 & 15 & 50.00 & 21 & 1.50 & 0 & 0.243 & 0.182 & -0.397 & 11 & 2.75 & 2.59 & 0 & 0.467 & 0.418 & -0.120 \\
\hline $\mathrm{T} 4$ & 15 & 57.14 & 23 & 1.64 & 0 & 0.314 & 0.225 & -0.430 & 10 & 2.50 & 2.21 & 0 & 0.383 & 0.330 & -0.169 \\
\hline T5 & 15 & 64.29 & 25 & 1.79 & 0 & 0.429 & 0.322 & -0.451 & 9 & 2.25 & 2.13 & 0 & 0.450 & 0.384 & -0.178 \\
\hline T6 & 15 & 50.00 & 24 & 1.71 & 0 & 0.200 & 0.219 & 0.013 & 10 & 2.50 & 2.26 & 0 & 0.450 & 0.351 & -0.295 \\
\hline $\mathrm{T} 8$ & 14 & 28.57 & 20 & 1.43 & 0 & 0.171 & 0.157 & -0.092 & 11 & 2.75 & 2.41 & 0 & 0.375 & 0.396 & 0.055 \\
\hline T9 & 15 & 64.29 & 25 & 1.79 & 1 & 0.271 & 0.282 & -0.062 & 11 & 3.00 & 2.77 & 2 & 0.283 & 0.437 & 0.359 \\
\hline T11 & 15 & 35.71 & 21 & 1.50 & 0 & 0.257 & \begin{tabular}{|l|l}
0.197 \\
\end{tabular} & -0.429 & 11 & 2.75 & 2.55 & 0 & 0.267 & 0.322 & 0.176 \\
\hline $\mathrm{T} 12$ & 15 & 64.29 & 24 & 1.71 & 0 & 0.343 & 0.265 & -0.319 & 10 & 2.50 & 2.33 & 0 & 0.217 & 0.265 & 0.188 \\
\hline T13 & 15 & 71.43 & 25 & 1.79 & 1 & 0.429 & 0.298 & -0.484 & 9 & 2.25 & 2.09 & 0 & 0.133 & 0.202 & 0.349 \\
\hline T15 & 15 & 57.14 & 25 & 1.79 & 0 & 0.300 & \begin{tabular}{|l|l|}
0.273 \\
\end{tabular} & -0.200 & 8 & 2.00 & 1.95 & 0 & 0.183 & 0.221 & 0.174 \\
\hline T16 & 15 & 50.00 & 24 & 1.71 & 0 & 0.186 & 0.221 & 0.073 & 13 & 3.25 & 2.67 & 0 & 0.283 & 0.328 & 0.141 \\
\hline T17 & 15 & 57.14 & 25 & 1.79 & 0 & 0.314 & 0.282 & -0.171 & 9 & 2.25 & 2.17 & 0 & 0.233 & 0.253 & 0.080 \\
\hline T18 & 15 & 57.14 & 25 & 1.79 & 0 & 0.243 & 0.260 & -0.011 & 9 & 2.25 & 2.17 & 0 & 0.150 & 0.257 & 0.425 \\
\hline $\mathrm{T} 21$ & 13 & 57.14 & 24 & 1.71 & 0 & 0.300 & 0.218 & -0.390 & 12 & 3.00 & 2.48 & 0 & 0.308 & 0.311 & 0.010 \\
\hline $\mathrm{T} 22$ & 15 & 50.00 & 22 & 1.57 & 0 & 0.386 & 0.259 & -0.629 & 9 & 2.25 & 1.96 & 0 & 0.267 & 0.224 & -0.201 \\
\hline $\mathrm{T} 23$ & 8 & 57.14 & 24 & 1.71 & 0 & 0.371 & 0.281 & -0.444 & 9 & 2.25 & 2.00 & 0 & 0.219 & 0.246 & 0.222 \\
\hline T29 & 15 & 57.14 & 26 & 1.86 & 0 & 0.286 & 0.259 & -0.202 & 12 & 3.00 & 2.51 & 1 & 0.200 & 0.264 & 0.248 \\
\hline Mean & 14.421 & 53.759 & 23.5 & 1.677 & 0.105 & 0.297 & 0.245 & -0.287 & 10.3 & 2.592 & 2.327 & 0.260 & 0.286 & 0.307 & 0.096 \\
\hline $\mathrm{SE}$ & 0.185 & 2.341 & 0.421 & 0.030 & 0.072 & 0.017 & 0.010 & 0.046 & 0.367 & 0.135 & 0.063 & 0.150 & 0.031 & 0.029 & 0.054 \\
\hline Total & 274 & 85.710 & 31 & 2.36 & 2 & 0.296 & 0.258 & -0.290 & 20 & & & 5 & & & \\
\hline
\end{tabular}


Table 5. Analysis of molecular variance (AMOVA): df - number of degrees of freedom; SSD - sum of squared deviation; MSD - mean squared deviation; $\Phi_{\mathrm{PT}}-$ the population genetic differentiation; $\mathrm{p}$ - testing probability; Nm - gene flow

\begin{tabular}{|c|c|c|c|c|c|c|c|c|c|}
\hline Marker & $\begin{array}{c}\text { Source } \\
\text { of variance }\end{array}$ & $\mathrm{df}$ & SSD & MSD & $\begin{array}{c}\text { Variance } \\
\text { component }\end{array}$ & $\begin{array}{c}\text { Percentage } \\
\text { of total } \\
\text { variance }(\%)\end{array}$ & $\Phi_{\mathrm{PT}}$ & $\mathrm{p}$ & $\mathrm{Nm}$ \\
\hline \multirow{3}{*}{ Isozyme } & amongst progeny & 18 & 100.2 & 5.6 & 0.615 & 20 & \multirow{3}{*}{0.198} & \multirow{3}{*}{0.01} & \multirow{3}{*}{1.015} \\
\hline & within progeny & 255 & 636.2 & 2.5 & 2.495 & 80 & & & \\
\hline & total & 273 & 736.4 & & 3.109 & 100 & & & \\
\hline \multirow{3}{*}{ SSR } & amongst progeny & 18 & 81.2 & 4.5 & 0.221 & 14 & \multirow{3}{*}{0.143} & \multirow{3}{*}{0.01} & \multirow{3}{*}{1.501} \\
\hline & within progeny & 255 & 338.3 & 1.3 & 1.327 & 86 & & & \\
\hline & total & 273 & 419.5 & & 1.548 & 100 & & & \\
\hline
\end{tabular}
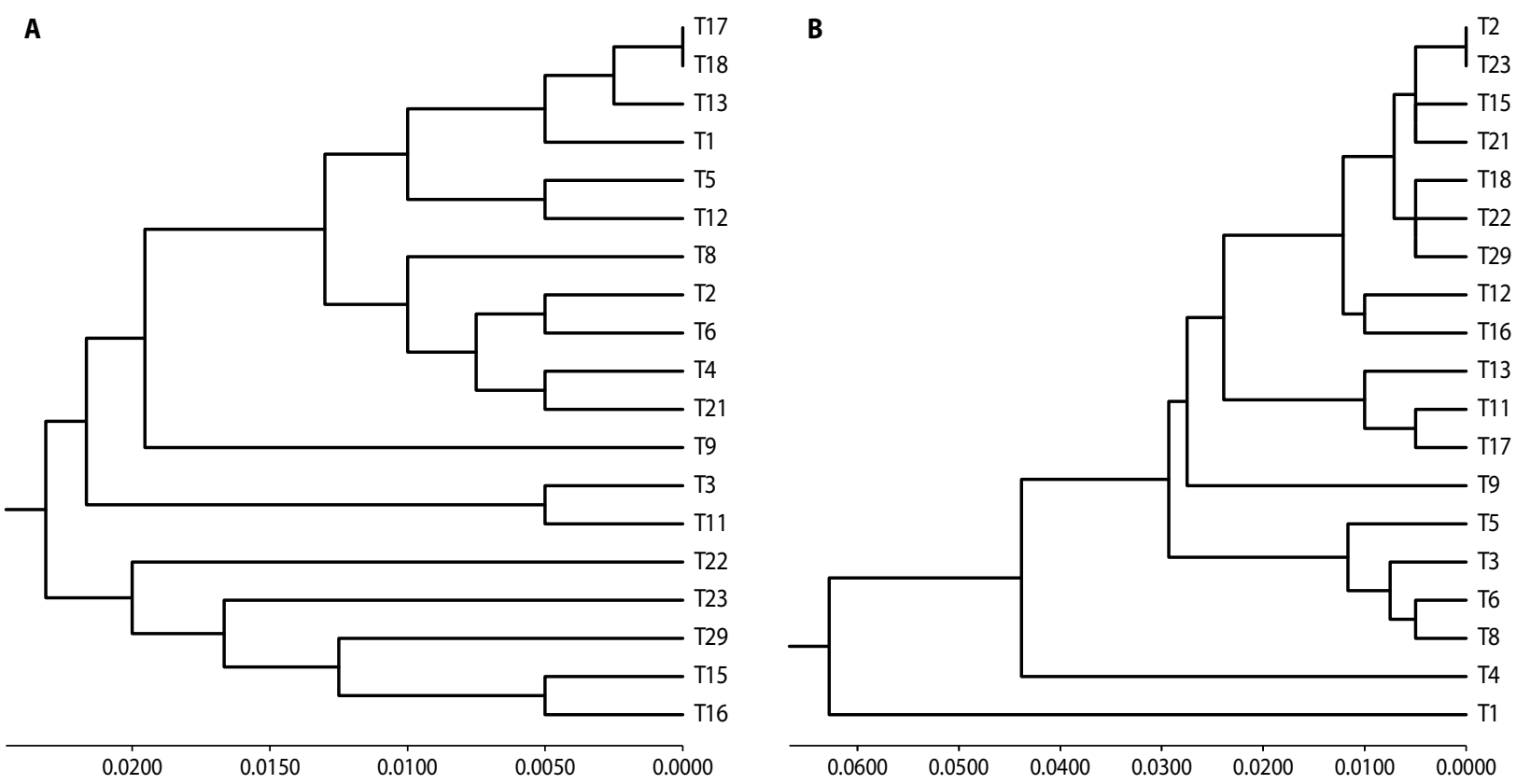

Figure 1. UPGMA dendrograms for progeny lines based on Nei genetic distances calculated via (A) isozyme and (B) nrSSR markers

The highest excess of heterozygotes occurred in progeny line $\mathrm{T} 22$.

Hierarchical AMOVA showed that the coefficient of gene differentiation $\left(\Phi_{\mathrm{PT}}\right)$ between progeny lines was 0.198 . Most genetic diversity $(80 \%)$ resulted from the variation within progeny lines, whereas the variation amongst progeny lines was $20 \%$ (Tab. 5).

Pairwise comparison of $\mathrm{F}_{\mathrm{ST}}$ showed the highest genetic differentiation between progeny lines $\mathrm{T} 8$ and $\mathrm{T} 23$ $\left(\mathrm{F}_{\mathrm{ST}}=0.234\right.$, significant at $\left.\mathrm{p}<0.01\right)$ and the lowest between progeny lines $\mathrm{T} 2$ and $\mathrm{T} 17\left(\mathrm{~F}_{\mathrm{ST}}=0.001\right)$ (data in documentation of work, does not attached).
Nei's (1972) genetic distances between 19 progeny lines ranged from 0.018 between progeny lines T17 and T18 to 0.114 between T3 and T29 (data in documentation of work, does not attached). On dendrogram (Fig. 1a), the progeny formed two groups. The first groups is divided into two subgroups: the first subgroup with progeny lines T17, T18, T13, T1, T5 and $\mathrm{T} 12$ and the second with T8, T2, T6, T4 and T21. The progeny lines T9, T3 and T11 join these two subgroups. The second group included progeny lines T22, T23, T29, T15 and T16. 


\section{Analysis of nrSSR}

From four to six alleles (A) were identified at each locus (Tab. 3b). At loci SF 333 and SF b5, an exact test for the Hardy-Weinberg equilibrium indicated a significant deficit of heterozygotes (HWE). Locus SF 1 expressed an excess of heterozygotes $\left(\mathrm{F}_{\mathrm{IS}}, \mathrm{F}_{\mathrm{IT}}\right)$. Loci SF 324 and SF 1 were in the Hardy-Weinberg equilibrium (HWE). The mean value of the inbreeding coefficient of an individual relative to the progeny line $\left(\mathrm{F}_{\mathrm{IS}}\right)$ was 0.117 ( $\mathrm{p} \leq 0.001)$, but relative to the population as a whole $\left(\mathrm{F}_{\mathrm{IT}}\right)$ was $0.186(\mathrm{p} \leq 0.001)$, indicating a deficit of heterozygotes. The genetic differentiation $\left(\mathrm{F}_{\mathrm{ST}}\right)$ was 0.105 , and the level of gene flow $(\mathrm{Nm})$ between the studied progeny lines was 2.172 migrants per generation.

Mean observed heterozygosity $\left(\mathrm{H}_{\mathrm{O}}=0.284\right)$ across the loci for all samples was lower than the mean expected heterozygosity $\left(\mathrm{H}_{\mathrm{E}}=0.308\right)$ under the Hardy-Weinberg expectations, but, totally, the progeny exhibited the Hardy-Weinberg equilibrium. The highest proportion of null alleles was discovered in locus SF b5, and across the loci for all samples, this was low and amounted to 0.053 .

The parameters of genetic variation for each progeny line were given in Table 4 . The highest number of alleles (A), the highest mean number of alleles per locus $\left(A_{L}\right)$ and allelic richness $\left(A_{R}\right)$ for all loci were detected in progeny line $\mathrm{T} 1$, and the lowest in T15. In sum, of the 20 alleles detected, 5 were unique to particular progeny lines: two private alleles $\left(\mathrm{A}_{\mathrm{P}}\right)$ in progeny lines $\mathrm{T} 1$ and $\mathrm{T} 9$ and one in progeny line T29. The highest value of observed heterozygosity $\left(\mathrm{H}_{\mathrm{O}}\right)$ was detected in progeny line $\mathrm{T} 3$, and the lowest in $\mathrm{T} 2$. Fixation indices $\left(\mathrm{F}_{\mathrm{IS}}\right)$ showed that 6 progeny lines $(\mathrm{T} 1, \mathrm{~T} 3, \mathrm{~T} 4, \mathrm{~T} 5$, T6 and T22) exhibited an excess of heterozygotes and 13 a deficit of heterozygotes. The highest deficit of heterozygotes occurred in progeny line $\mathrm{T} 2$.

AMOVA showed that $14 \%$ of the total variability was present amongst progeny lines and the remaining (86\%) was attributable to differences within progeny lines (Tab. 5). These differences are statistically significant $\left(\Phi_{\mathrm{PT}}=0.143 ; \mathrm{p}<0.01\right)$. The overall gene flow $(\mathrm{Nm})$ amongst progeny lines was low and amounted to 1.5 , which gives an estimate of the average number of migrants between all the studied progeny per generation.

$\mathrm{F}_{\mathrm{ST}}$ showed the highest genetic differentiation between progeny lines $\mathrm{T} 1$ and $\mathrm{T} 13\left(\mathrm{~F}_{\mathrm{ST}}=0.341\right.$, significant at $\mathrm{p}<0.0001)$ and the lowest between progeny lines T3 and $\mathrm{T} 6$ and also $\mathrm{T} 6$ and $\mathrm{T} 21\left(\mathrm{~F}_{\mathrm{ST}}=0.001\right)$, and the mean value was equal to $0.11 . \mathrm{F}_{\mathrm{ST}}$ averaged across the loci also indicated that progeny lines T1, T4, T5 and T9 differed most significantly from the others (data in documentation of work, does not attached).

On the basis of the calculated Nei genetic distances, a UPGMA dendrogram was constructed (Fig. 1b). The progeny formed three groups: the first with the progeny of T2, T23, T15, T22, T21, T12, T18, T29 and T16; the second with the progeny of T11, T17 and T13. To these two groups joined the progeny T9. An additional third group included progeny of T3, T6, T8 and T5. To these progeny, offspring $\mathrm{T} 4$ is linked and $\mathrm{T} 1$ is the most differentiated progeny. Nei's (1972) genetic distances between 19 progeny lines ranged from 0.004 between progeny lines T2 and T23 to 0.245 between $\mathrm{T} 1$ and $\mathrm{T} 13$ (data in documentation of work, does not attached).

\section{Discussion}

Genetic research into the maternal silver fir from the Tisovik Reserve has been relatively intensive over the past two decades, since the dieback of this population and the rapidly decreasing number of fir trees was first noticed. On isozyme markers, this stand was analysed by Mejnartowicz (1996a, 1996b) on 11 maternal trees (from 20 which still growing there) using 11 enzyme systems (17 loci) and by Goncharenko and Savitsky (2000) on 15 enzyme systems (22 loci).

Our results obtained from isozyme markers (12 loci, nine enzyme systems) showed that the value of polymorphic loci ( $\mathrm{P} \%$ ) ranged from $28.57 \%$ (in the $\mathrm{T} 8$ progeny line) to $71.43 \%$ (in the T13 progeny line) with an average value of $53.76 \%$, whereas in maternal trees, (Mejnartowicz 1996a, 1996b) $21.49 \%$ of polymorphic loci was detected. We discovered that the mean number of alleles per locus $\left(\mathrm{A}_{\mathrm{L}}\right)$ is 1.677 , slightly more than that in maternal trees, $A_{L}=1.353$ (Mejnartowicz 1996a, 1996b) and 1.409 (Goncharenko and Savitsky 2000). The mean value of expected heterozygosity $\left(\mathrm{H}_{\mathrm{E}}\right)$ was 0.245 and observed heterozygosity $\left(\mathrm{H}_{\mathrm{O}}\right)$ 0.297; these values were higher than that in maternal trees: $\mathrm{H}_{\mathrm{E}}=0.079$ and $\mathrm{H}_{\mathrm{O}}=0.123$ (Mejnartowicz 1996a, 1996b) and, respectively, 0.111 and 0.127 (Goncharenko and Savitsky 2000). So progeny, similar to maternal trees, demonstrated the excess of heterozygotes, what confirm the inbreeding indices $\mathrm{F}_{\mathrm{IS}}=-0.210$ and $\mathrm{F}_{\mathrm{IT}}$ $=-0.024$ for progeny and less for maternal trees $(-0.035$; 
0.005, respectively) (Goncharenko and Savitsky 2000). The largest excess of heterozygotes was noted in progeny lines T22 $(-0.629)$ and T1 $(-0.516)$ and the smallest in T18 (-0.011). Only two progeny lines $-\mathrm{T} 6$ and T16 - demonstrated a slight excess of homozygotes $(0.013$ and 0.073 , respectively). Measurement of genetic differentiation between progeny lines $\left(\mathrm{F}_{\mathrm{ST}}=0.166\right)$ showed a greater level of variation than maternal population (0.038) (Goncharenko and Savitsky 2000). This conclusion confirmed the result of AMOVA, where $\Phi_{\mathrm{PT}}$ was 0.198 .

Mejnartowicz (1996a, 1996b) compared Tisovik to eight other stands from Poland (Tomaszów Lubelski, Skarżysko, Komańcza, Międzygórze and four manmade stands from Białowieża Forest). He discovered that Tisovik is characterised by the lowest mean number of alleles per locus, percentage of polymorphic loci and expected heterozygosity with comparison to other populations $\left(\mathrm{A}_{\mathrm{L}}\right.$ ranged from 1.412 to $1.580, \mathrm{P} \%$ from 23.529 to 41.176 and $\mathrm{H}_{\mathrm{E}}$ from 0.123 to 0.158 ) and showed excess of heterozygosity similar to that in case of Skarżysko and three stands from Białowieża. A dendrogram constructed based on the Nei genetic distances showed that Tisovik fir is the most different from other populations. Mejnarowicz (1996a, 1996b) concluded that the Tisovik population is threatened with extinction.

Goncharenko and Savitsky (2000) also compared the Tisovik population to six other populations from Ukraine (Drohobycz, Delyatyn and Worochta) and Poland (Jata, Roztocze and Labowiec) and thus to populations from the north-eastern border of the species range. These populations were characterised by a higher number of alleles per locus (from 1.500 to 1.818 ) and a higher expected heterozygosity - from 0.113 to 0.147 (except Jata 0.100) - than was the case in Tisovik. Similar to Tisovik, four populations displayed an excess of heterozygotes and two - Jata and Drohobycz - an excess of homozygotes. Jata is a population that is growing on the border of the range, but Drohobycz is growing in dense distribution. Nei's genetic distances and a dendrogram constructed on the basis of these data showed that Tisovik fir is the most different from other populations - similar to Mejnartowicz's study (1996a, 1996b). The highest value of the Nei genetic distance was between Tisovik and Worochta (Ukraine). These two sites are localised the farthest from each other (about $520 \mathrm{~km}$ ).

Comparing the populations studied by Mejnartowicz (1996a, 1996b) and Goncharenko and Savitsky (2000) to progeny of Tisovik, it can be concluded that almost all genetic parameters were higher in Tisovik progeny. However, progeny of Jata, Roztocze and Labowiec are characterised by higher values of $\mathrm{A}_{\mathrm{L}}$ (from 1.87 to 2.12) than its maternal trees but lower values of $\mathrm{H}_{\mathrm{O}}$ (from 0.105 to 0.132 ) and $\mathrm{H}_{\mathrm{E}}$ (from 0.105 to 0.112 ). Similar to Tisovik progeny, other offspring of Polish provenances exhibit slightly excess of heterozygotes $\left(\mathrm{F}_{\mathrm{IS}}\right.$ from -0.010 to -0.146$)$ and congruent level of differentiation $\left(\mathrm{F}_{\mathrm{ST}}=\right.$ 0.166 for Tisovik progeny and from 0.151 to 0.193 for other studied Polish offspring) (unpublished, own data).

There are a very few papers (Cremer et al. 2006, Pawlaczyk et al. 2010, Cremer et al. 2012, Gömöry et al. 2012, Cvrčková et al. 2015) describing the variation of silver fir in nuclear microsatellite DNA markers. It is caused by the difficulties in finding polymorphic loci in this taxa. Cremer et al. (2006) had checked the variability (14 loci of SSR) amongst $A$. alba populations in Bulgaria, France, Germany and Switzerland. Four loci were the same in our and Cremer et al. (2006) papers. Their values of expected and observed heterozygosity and the number of detected alleles were as follows: SF 1 $(\mathrm{Ho}=0.333, \mathrm{He}=0.598, \mathrm{~A}=3)$, SF $333(\mathrm{Ho}=0.391$, $\mathrm{He}=0.792, \mathrm{~A}=6)$, SF $324(\mathrm{Ho}=0.333, \mathrm{He}=0.348$, $\mathrm{A}=3)$ and $\mathrm{SF}$ b5 $(\mathrm{Ho}=0.682, \mathrm{He}=0.883, \mathrm{~A}=5)$. Comparing these values with our results, we found lower values, particularly for locus $\mathrm{SF}$ b5 $(\mathrm{Ho}=0.062, \mathrm{He}=$ 0.110 ), but higher numbers of alleles from 4 to 6 (only in locus SF 333 detected the same number of alleles). Each loci studied by Cremer et al. (2006) showed excess of homozygotes, similar to that in Tisovik progeny, except locus SF 1, which exhibited their excess.

Another Cremer et al.'s (2012) study was conducted in the Black Forest, a low mountain range in the southwestern part of Germany. He compared mother trees to seeds on five SSR loci (three the same like in our work) and reported that values of expected and observed heterozygosity and the number of detected allelic richness were as follows: $\mathrm{SF} 1\left(\mathrm{Ho}=0.534, \mathrm{He}=0.539, \mathrm{~A}_{\mathrm{R}}=5\right)$, SF $333\left(\mathrm{Ho}=0.489, \mathrm{He}=0.720, \mathrm{~A}_{\mathrm{R}}=6\right)$, and $\mathrm{SF}$ b5 $\left(\mathrm{Ho}=0.467, \mathrm{He}=0.471, \mathrm{~A}_{\mathrm{R}}=7\right.$ ) for forest stands and for seeds: SF $1\left(\mathrm{Ho}=0.441, \mathrm{He}=0.509, \mathrm{~A}_{\mathrm{R}}=7\right), \mathrm{SF} 333$ $\left(\mathrm{Ho}=0.557, \mathrm{He}=0.693, \mathrm{~A}_{\mathrm{R}}=7\right)$ and $\mathrm{SF}$ b5 $(\mathrm{Ho}=0.457$, $\left.\mathrm{He}=0.529, \mathrm{~A}_{\mathrm{R}}=8\right)$. So in seeds, more alleles were found in every loci, and both mother trees and seeds were characterised by excess of homozygotes. However, this excess was much larger for seeds in loci SF 1 
and SF b5 and for mother trees in locus SF 333. The values of $\mathrm{H}_{\mathrm{O}}$ and $\mathrm{H}_{\mathrm{E}}$ for seeds were similar to our results especially in loci SF 1 and SF 333, but much higher in locus SF b5. We found less number of alleles in comparison especially to seeds and, to a lesser extent, mature trees. We analysed seedlings (so middle phase of trees growth) but only in one small and isolated population.

Lately, Cvrčková et al. (2015) had studied eight populations of silver fir from Czech Republic using eight microsatellites markers, but only one locus was the same like in our research (SF 1). Cvrčková et al. (2015) detected five alleles in this locus and the expected and observed heterozygosity are as follows: $\mathrm{H}_{\mathrm{E}}=0.451$ and $\mathrm{H}_{\mathrm{O}}=0.473$. In Tisovik progeny, four alleles were detected and the expected and observed heterozygosity are 0.303 and 0.386 , respectively, so locus SF 1 in these two cases showed excess of heterozygotes. Three other loci studied by Cvrčková et al. (2015) also showed similar pattern of homozygote deficiency.

Comparing the results obtained from 4 SSR and 12 isozyme loci, it may be concluded that the mean value of expected heterozygosity $\left(\mathrm{H}_{\mathrm{E}}\right)$ was at a similar level as in isozymes ( 0.308 and 0.299$)$, but that of observed heterozygosity $\left(\mathrm{H}_{\mathrm{O}}\right)$ was lower $(0.284$ and 0.345$)$. Four progeny lines (T5, T9, T11 and T21) had similar values of observed heterozygosity detected from isozyme and SSR markers, six (T1, T3, T4, T6, T8, T16) had higher values of observed heterozygosity for SSR markers and the remaining nine for isozymes (Fig. 2a). The parameters of inbreeding $\left(\mathrm{F}_{\mathrm{IS}}\right)$ exhibited the fact that offspring were characterised by a slight excess of homozygotes (the largest was noted in progeny lines $\mathrm{T} 2$ and $\mathrm{T} 18$, and the smallest in T21). Six progeny lines (T1, T3, T4, T5, T6 and T22) demonstrated slight excesses of heterozygotes.
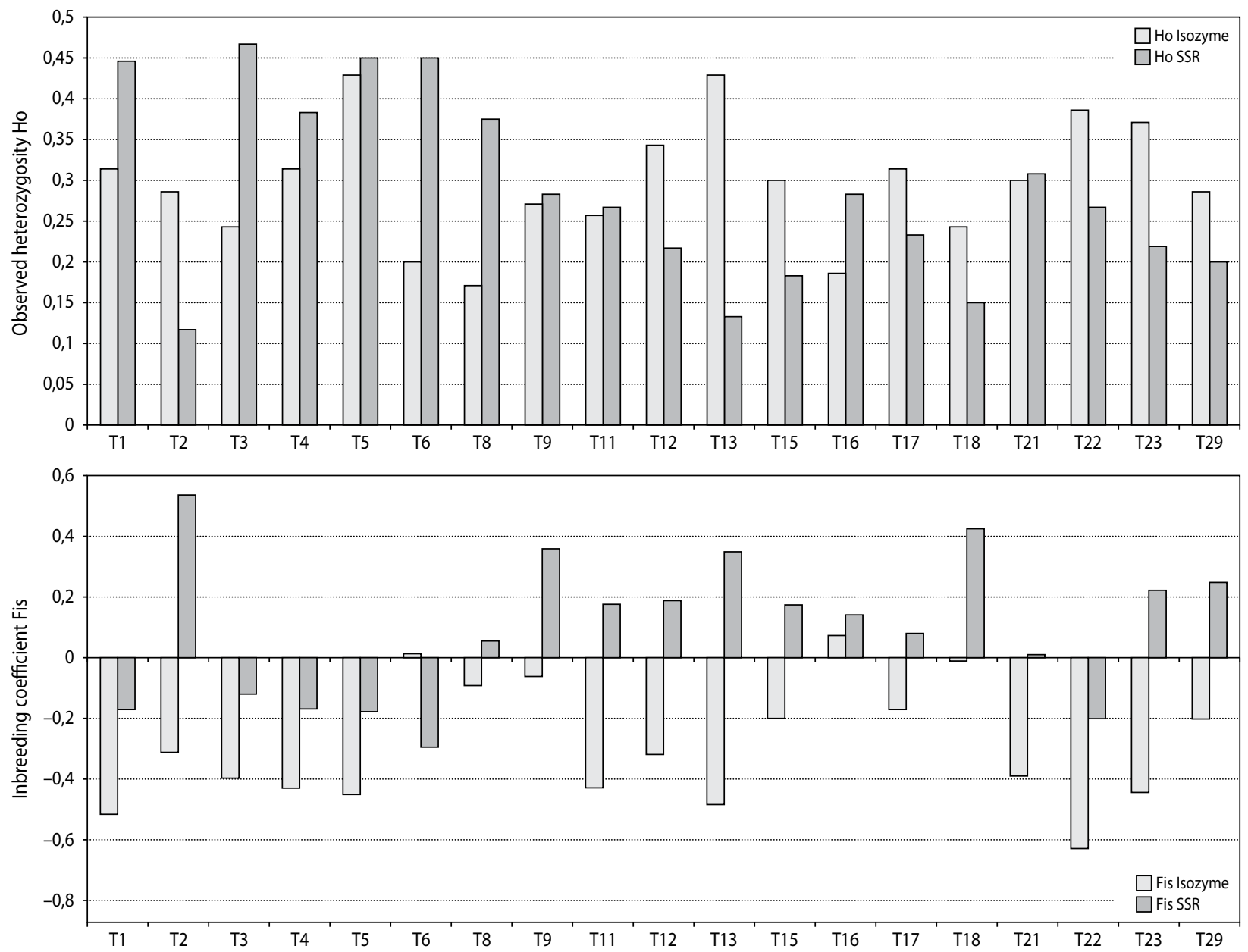

Figure 2. Comparison between isozyme and SSR markers for (A) observed heterozygosity and (B) inbreeding ind 
Only progeny line T6 showed an excess of homozygotes in isozymes and a deficiency in microsatellite markers (Fig. 2b). Measures of genetic differentiation amongst progeny lines $\left(\mathrm{F}_{\mathrm{ST}}=0.105 ; \Phi_{\mathrm{PT}}=0.143\right)$ showed smaller values than that detected by isozyme markers. The gene flow $(\mathrm{Nm})$ amongst progeny lines was low (1.015 for isozyme and 1.501 for DNA markers), what may give evidence about internal division in this population on subgroups. It may be a result of more frequent pollination by some paternal trees (e.g. trees $6,7,8,9,13$ or 18 , which are growing on the middle of this stand) than others that may have less chance on pollination because growing on the border of this population (Pawlaczyk et al. 2005). The presence of the private alleles both in SSR and isozyme markers may be effected by pollination of foreign pollen from Polish part of Białowieża Forest where in 1920s and 1930s of XX century had planted the seedling of silver fir of unknown origin (Mejnartowicz 1996a, 1996b, Korczyk et al. 1997).

Describing diversity of the offspring of Tisovik Reserve using SSR markers and comparing to other Polish populations from dense range (Jata Reserve - near Lublin, Kamienna Góra Reserve - Roztocze National Park and Labowiec Reserve - Beskid Sądecki) (Pawlaczyk et al. 2010), it may be concluded that Tisovik progeny are characterised by smaller mean number of alleles per locus $\left(\mathrm{A}_{\mathrm{L}}\right)$ and lower observed $\left(\mathrm{H}_{\mathrm{O}}\right)$ and expected heterozygosity $\left(\mathrm{H}_{\mathrm{E}}\right)$. In Pawlaczyk et al.'s (2010) paper, two loci were analysed (SF 1 and SF 333), and they detected three to five alleles per locus SF 1 and eight alleles per locus SF 333. Values of observed heterozygosity $\left(\mathrm{H}_{\mathrm{O}}\right)$ for SF 1 ranged from 0.428 for Jata to 0.467 for Kamienna Góra and those of expected heterozygosity $\left(\mathrm{H}_{\mathrm{E}}\right)$ ranged from 0.507 for Kamienna Góra to 0.517 for Jata. Respectively, these values for Tisovik were 0.386 for $\mathrm{H}_{\mathrm{O}}$ and 0.303 for $\mathrm{H}_{\mathrm{E}}$. Similarly, values of SF 333 ranged from 0.607 for Kamienna Góra to 0.627 for Łabowiec and those of $\mathrm{H}_{\mathrm{E}}$ ranged from 0.743 for Kamienna Góra to 0.755 for Łabowiec. Respectively, these values for Tisovik were 0.552 for $\mathrm{H}_{\mathrm{O}}$ and 0.658 for $\mathrm{H}_{\mathrm{E}}$. So Tisovik progeny are characterised by a lower observed and expected heterozygosity. Progeny of populations from dense range showed excess of homozygotes in these two loci, whilst Tisovik progeny in locus SF 333, but in locus SF 1 excess of heterozygotes. However, when four SSR loci are taken into account, the deficiency of heterozygotes was detected.
Differences in the levels of heterozygosity in Tisovik offspring between used markers may be the result of inbreeding and genetic drift, which is very likely in a small and isolated population. A similar situation has been described in Pinaceae by many authors, such as Potter et al. (2008) in Fraser fir and Głowacki et al. (2005) in dwarf mountain pine. Potter et al. (2008) detected a bigger deficit of heterozygosity in microsatellite markers than in enzyme markers. The consistently significant deficiency of heterozygotes across loci and populations was explained by Potter et al. (2008) on the basis of inbreeding, the Wahlund effect caused by spatial substructuring of intrapopulation demes and out of Hardy-Weinberg equilibrium than any overriding effect of null alleles.

The grade of variability may also be a result of long selection and adaptation to rapidly changing environmental factors in the Białowieża Primeval Forest after the last glaciation. Fir is especially sensitive to the low temperatures present in February and the impact of the continental climate in this region (Klisz et al. 2016). The differences in heterozygosity found between the SSR and isozyme markers may result from the fact that proteins are more sensitive to selection. So homozygotes are removed from a population and heterozygotes are maintained as they are more suited to the environmental conditions.

Tisovik Reserve is a small population that counted only 20 mature trees and had been damaged by anthropogenic changes to sites. The impact of population size and human activity on the level of diversity of silver fir has been observed in the Sudeten Mts., where this site is considerably smaller than the population in the Carpathian Mts. Lewandowski et al. (2001) on 9 enzyme systems with 13 loci detected low number of alleles per locus (from 1.23 to 1.54) in the Sudeten Mts. and a low grade of variation. A comparison between the Sudeten and Carpathian Mts. silver fir in Poland was carried out by Mejnartowicz (2004) on 14 enzyme systems with 28 loci. He described the great Nei genetic distance (from 0.173 to 0.252 ) that separated the Sudeten and Carpathian populations and was the result of restricted gene flow between populations and their isolation. The Sudeten populations were characterised by a lower level of observed and expected heterozygosity ( 0.130 and 0.129 , respectively) than the Carpathian ones ( 0.275 and 0.269 , respectively) and lower genetic diversity. Another example of the impact of population 
size on diversity was given by Mejnartowicz (2003) on 14 enzyme systems with 28 loci. He studied silver fir from the Western Beskid Mts. (southern Poland), which is characterised by a special orographic formation causing differentiation in plant populations and limiting the number of trees. He discovered that the Western Beskid Mts. had a slightly smaller genetic variability and diversity in comparison to the Eastern Beskid Mts. Both were characterised by an excess of heterozygotes $\left(F_{I S}=-0,017\right.$ for Eastern and $F_{I S}=-0.064$ for Western Beskid), but the Eastern Beskid Mts. had a greater heterozygosity and a greater number of effective alleles.

Higher genetic diversity as a buffer to the potential threat of dramatic change in climatic conditions was indicated by Longauer et al. (2003) on 11 enzyme systems with 18 loci. They described this phenomenon as the result of vulnerability (lower adaptability). They compared populations from northern and southern regions of fir range and detected that northern populations were characterised by a slight excess of homozygotes, a lower total number of alleles, a lower mean number of alleles per locus and a lower grade of variation than populations from southern regions, which are more exposed to rapidly changing environmental factors.

\section{Conclusions}

Tisovik is a small, isolated population that has limited number of individuals to crossing. In such population, the higher number of homozygotes is expected as a result of inbreeding. In addition, studied firs were 15-year-old (in juvenile phase), where the selection on homozygotes takes place (which was detected by SSR markers). On the other hand, progeny of Tisovik showed high level of differentiation as an offspring of small, isolated stand. Distinctiveness of some progeny lines and the presence of the private alleles may be the result of pollination from Polish part of Białowieża Forest. Another reason of high variation may be such that some paternal trees may take part into pollination with more frequency than others. So the substructuring of population is observed (dendrograms), and the deficit of heterozygotes detected may be ostensible as a result of Wahlund effect. Besides, isozyme markers detected excess of heterozygotes what may confirm this thesis and be caused by the bottle neck effect postulated by Mejnartowicz (1996a, 1996b). Such pattern of genetic structure can also be an effect of harsh environmental conditions exerting selection pressure and modifying the genetic composition of this population.

\section{ACKNOWLedgments}

The authors wish to thank Prof. A.F. Korczyk from the Forest Research Institute in Białowieża and the Białystok University of Technology for providing the plant material for the study.

This project was supported by the Polish National Science Centre under grant number NN 305373938.

\section{References}

Boys J., Cherry M., Dayanandan S. 2005. Microsatellite analysis reveals genetically distinct populations of red pine (Pinus resinosa Pinaceae). American Journal of Botany, 92, 833-841, doi: 10.3732/ ajb.92.5.833.

Breitenbach-Dorfer M., Konnert M., Pinsker W., Starlingen F., Geburek T. 1997. The contact zone between two migration routes of silver fir, Abies alba (Pinaceae), revealed by allozyme studies. Plant Systematics and Evololution, 206, 259-272.

Celiński K., Pawlaczyk E.M., Wojnicka-Półtorak A., Chudzińska E., Prus-Głowacki W. 2013. Crossspecies amplification and characterization of microsatellite loci in Pinus mugo Turra. Biologia, 68 (4), 621-626, doi: 10.2478/s11756-013-0189-z.

Cheliak W.M., Pitel J.A. 1984. Techniques for starch gel electrophoresis of enzymes from forest tree species. J.A. Canadian Forestry Service, Petawawa National Forestry Institute, Chalk River, Ontario, Information Report PI-X-42, p. 49.

Chudzińska E., Celiński K., Pawlaczyk E.M, WojnickaPółtorak A., Diatta J.B. 2016. Trace element contamination differentiates the natural population of Scots pine: evidence from DNA microsatellites and needle morphology. Environmental Science and Pollution Research, 23 (21), 22151-22162.

Cremer E., Liepelt S., Sebastiani F., Buonamici A., Michalczyk M., Ziegenhagen B., Vendramin G.G. 2006. Indentification and characterization of nuclear microsatellite loci in Abies alba Mill. Molecu- 
lar Ecology Notes, 6, 374-376, doi: 10.1111/j.14718286.2005.01238.x.

Cremer E., Ziegenhagen B., Schulerowitz K., Mengel Ch., Donges K., Bialozyt R., Hussendörfer E., Liepelt S. 2012. Local seed dispersal in European silver fir (Abies alba Mill.): lessons learned from a seed trap experiment. Trees, 26, 987-996, doi: 10.1007/s00468-012-0676-9.

Cvrčková H., Máchová P., Malá J. 2015. Use of nuclear microsatellite loci for evaluating genetic diversity among selected populations of Abies alba Mill. in the Czech Republic. Journal of Forest Science, 61 (8), 345-351, doi: 10.17221/25/2015-JFS.

Doyle J.J., Doyle J.L. 1990. Isolation of plant DNA from fresh tissue. Focus, 12, 13-15.

Excoffier L., Laval G., Schneider S. 2005. Arlequin ver. 3.0: An integrated software package for population genetics data analysis. Evolutionary Bioinformatics Online, 1, 47-50.

Głowacki-Prus W., Bączkiewicz A., Wysocka D. 2005. Clonal structure of small, isolated populations of Pinus mugo Turra from peatbogs in the Tatra Mts. Acta Biologica Cracoviensa series Botanica, 47 (2), $1-7$.

Goncharenko G.G., Savitsky B.P. 2000. Population and genetic resources of silver fir in Belarus. National Academy of Science of Belarus, Forest Institute, Gomel, Belarus, 1-121.

Goudet J. 1995. FSTAT version 1.2: a computer program to calculate F-statistics. Journal of Heredity, 86, 485-488.

Goudet J. 2001. FSTAT, a program to estimate and test gene diversities and fixation indices (version 2.9.3). Available from http://www.unil.ch/izea/softwares/ fstat.html. Updated from Goudet (1995).

Gömöry D., Paule L., Krajmerová D., Romšáková I., Longauer R. 2012. Admixture of genetic lineages of different glacial origin: a case study of Abiese alba Mill. in the Carpathians. Plant Systematics and Evolution, 298, 703-712, doi: 10.1007/s00606011-0580-6.

Górski S. 1829. O roślinach żubrom upodobanych, jako też innych w puszczy Białowiezkiey. Dziennik Wileński, 9, 207-217.

Hussendörfer E., Konnert M., Bergmann F. 1995. Inheritance and linkage of isozyme variants of silver fir (Abies alba Mill.). Forest Genetics, 2, 29-40.
Klisz M., Jastrzębowski S., Ukalska J., Przybylski P., Matras J., Mionskowski M. 2016. The vulnerability of silver fir populations to damage from late frosts (in Polish with English summary). Forest Research Papers, 77 (1), 24-31.

Konnert M., Bergmann F. 1995. The geographical distribution of genetic variation of silver fir (Abies alba, Pinaceae) in relation to its migration history. Plant Systematics and Evolution, 195, 19-30.

Korczyk A.F. 1999. Evaluation of the genetic and breeding value of natural populations of silver fir $(A b$ ies alba Mill.) from the eastern range of its occurrence in Poland (in Polish with English summary). Wydawnictwo Akademii Rolniczej w Krakowie. Zeszyty Naukowe, 61, 155-170.

Korczyk A.F. 2015a. The „Tisovik” reserve of Silver fir in the Belarusian national park „Belavezhskaya Pushcha" (in Polish with English summary). Leśne Prace Badawcze, 76 (1), 18-36.

Korczyk A.F. 2015b. The ancestral conservative tillage of silver fir in the "Tisovik” reserve of the Białowieża Primeval Forest (in Polish with English summary). Leśne Prace Badawcze, 76 (2), 153-167.

Korczyk A.F., Kawecka A., Martysevič V.V., Strelkov A.Z. 1997. European fir (Abies alba Mill.) natural stand in Białowieża Primeval Forest (in Polish with English summary). Prace Instytutu Badawczego Leśnictwa, seria A, 837, 27-62.

Larsen J.B. 1986. Das Tannensterben: Eine neue Hypothese zur Klärung des Hintergrundes dieser rätselhaften Komplexkrankheit der Weißtanne (Abies alba Mill. ). Centralblatt für das gesamte Forstwesen, 105, 381-396.

Lewandowski A., Filipiak M., Burczyk J. 2001. Genetic variation of Abies alba in Polish part of Sudety Mts. Acta Societatis Botanicorum Poloniae, 70 (3), 215-219.

Liepelt S., Cheddadi R., de Beaulieu J.-L., Fady B., Gömöry D., Hussendörfer E., Konnert M., Litt T., Longauer R., Terhürne-Berson R., Ziegenhagen B. 2009. Postglacial range expansion and its genetic imprints in Abies alba (Mill.) - A synthesis from paleobotanic and genetic data. Review of Palaeobotany and Palynology, 153, 139-149.

Longauer R. 1994. Genetic differentiation and diversity of European silver fir in Eastern part of its natural range. EDER, In. (Zusammengest.): 7 IUFRO 
Tannensymposium vom 31.10.-4.11. 1994. in Altensteig, Deutschland.

Longauer R., Paule L., Andonoski A. 2003. Genetic diversity of southern populations of Abies alba Mill. Forest Genetics, 10 (1), 1-9.

Masternak K., Niebrzydowska B., Głębocka K. 2015. Genetic variation of silver fir (Abies alba Mill.) preserved in the Katowice Forest District (in Polish with English summary). Leśne Prace Badawcze, 76 (4), 315-321.

Mejnartowicz L. 1996a. Cisovka - the relict population of Abies alba and its relationship to man-made silver fir stands in Białowieża Primeval Forest. Acta Societatis Botanicorum Poloniae, 65 (3/4), 319-328. Mejnartowicz L. 1996b. Origin of silver fir stands in Białowieża Primeval Forest. In: Biodiversity Protection of Białowieża Primeval Forest (eds.: P. Paschaslis, S. Zajączkowski). Warszawa, Poland, 35-50.

Mejnartowicz L. 2003. Genetic analysis of silver-fir populations in the Beskids. Acta Societatis Botanicorum Poloniae, 72 (2), 115-119.

Mejnartowicz L. 2004. Genetic analysis of silver-fir populations in the North Carpathian and Sudeten Mountains. Acta Societatis Botanicorum Poloniae, 73 (4), 285-292.

Nei M. 1972. Genetic distance between populations. The American Naturalist, 106, 238-292.

Nei M. 1978. Estimation of average heterozygosity and genetic distance from a small numbers of individuals. Genetics, 89, 583-590.

Pawlaczyk E.M., Grzebyta J., Bobowicz M.A., Korczyk A.F. 2005. Individual differentiation of Abies alba Mill. population from the Tisovik Reserve. Variability expressed in morphology and anatomy of needles. Acta Biologica Cracoviensa Series Botanica, 47 (2), 137-144.

Pawlaczyk E.M., Chudzińska E., Bobowicz M.A. 2010. Genetic variability of four provenances progeny of silver fir (Abies alba Mill.) expressed in microsatellite nuclear DNA polymorphism (nSSRs) (in Polish with English summary). Zeszyty Problemowe Postępów Nauk Rolniczych, 555, 319-332.

Peakall R., Smouse P.E. 2006. GENALEX 6: genetic analysis in Excel. Population genetic software for teaching and research. Molecular Ecology Notes, 6, 288-295.
Potter K.M., Frampton J., Josserand S.A., Nelson C.D. 2008. Genetic variation and population structure in Fraser fir (Abies fraseri): a microsatellite assessment of young trees. Canadian Journal of Forest Research, 38, 2128-2137. doi: 10.1139/X08-064.

Raymond M., Rousset F. 1995. Genepop. Version-1.2. Population genetics software for exact tests and ecumenicism. Journal of Heredity, 86, 248-249.

Sánchez-Robles J.M., Balao F., García-Castaño J.L., Terrab A., Navarro-Sampedro L., Talavera S. 2012. Nuclear microsatellite primers for the endangered relict fir, Abies pinsapo (Pinaceae) and crossamplification in related mediterranean species. International Journal of Molecular Science, 13, 14243-14250, doi: 10.3390/ijms131114243.

Stern K., Roche L. 1974. Genetics of forest ecosystems. Ecological Studies 6. 330 S., 70 Abb. Springer-Verlag, Berlin-Heidelberg-New York.

Tamura K., Stecher G., Peterson D., Filipski A., Kumar S. 2013. MEGA6: Molecular Evolutionary Genetics Analysis Version 6.0. Molecular Biology and Evolution, 30, 2725-2729.

van Oosterhout C., Hutchinson W.F., Wills D.P.M., Shipley P. 2004. Micro-Checker: Software for identifying and correcting genotyping errors in microsatellite data. Molecular Ecology Notes, 4, 535-538, doi: 10.1111/j.1471-8286.2004.00684.x.

van Oosterhout C., Weetman D., Hutchinson W.F. 2006. Estimation and adjustment of microsatellite null alleles in nonequilibrium populations. Molecular Ecology Notes, 6, 255-256, doi: 10.1111/j.14718286.2005.01082.x.

Vendramin G.G., Degen B., Petit R.J., Anzidei M., Madaghiele A., Ziegenhagen B. 1999. High level of variation at Abies alba chloroplast microsatellite loci in Europe. Molecular Ecology, 8, 1117-1126.

Watterson G.A. 1977. Heterosis or neutrality? Genetics, 85, 789-814.

Wright S. 1978. Evolution and the genetics of populations. Vol 4. Variability within and among natural populations. University of Chicago Press, Chicago.

Yeh F., Rongcai Y., Boyle T. 2000. POPGENE-1.32: A free program for the analysis of genetic variation among and within populations using co-dominant and dominant markers. Department of Renewable Resources at the University of Alberta, Canada. at http://www.ualberta.ca/ fyeh/index.htm. 